\title{
Commemorative plaques
}

\author{
R. Bairsto ${ }^{1}$ and S. Gelbier ${ }^{* 2}$
}

Please send any ideas for feature articles for consideration to:

Ruth Doherty,

Managing Editor,

British Dental Journal,

The Macmillan Building,

4-6 Crinan Street,

London,

N1 9XW

Email: r.doherty@nature.com

Earlier this year English Heritage, the BDA Museum and The Lindsay Society for the History of Dentistry unveiled a plaque to Lilian Lindsay (1871-1960). This paper outlines the history and administration of the blue plaque scheme and celebrates the contributions made by dentists who have been commemorated with plaques.

\section{THE BLUE PLAQUE SCHEME}

Commemorative plaques are a common sight on buildings in London and other cities, towns and villages across the UK. There are at least 300 plaque schemes that exist in the UK at the present time. ${ }^{1}$ Such schemes are run by a range of different bodies and organisations including local authorities, civic societies and local history groups. Best known of these is the London-wide blue plaque scheme, which has been administered by English Heritage since 1986 and works alongside other plaque initiatives run by groups and bodies such as Westminster City Council and the City of London Corporation. In total there are around 1,800 plaques in the capital, 880 of which belong to the English Heritage scheme. ${ }^{1}$

The idea of placing memorial tablets on the houses of illustrious historical figures was first mooted in the House of Commons in 1863 by the politician and reformer William Ewart (1798-1869). ${ }^{2}$ From the outset, the aim of the scheme was to celebrate the link between the person and the building and to encourage the preservation of houses of historic interest. The initial proposal received widespread support and the scheme was established

\footnotetext{
Head of Museum Services at the British Dental Association Museum, 64 Wimpole Street, London, W1G8YS. r.bairsto@bda.org; ${ }^{2}$ Unit for the History of Dentistry, KCL Dental Institute, floor 18, Dental Tower Guy's Hospital, St Thomas's Street, London SE1 9RT

${ }^{*}$ Correspondence to: Professor Stanley Gelbier Email:sgelbier@yahoo.co.uk
}

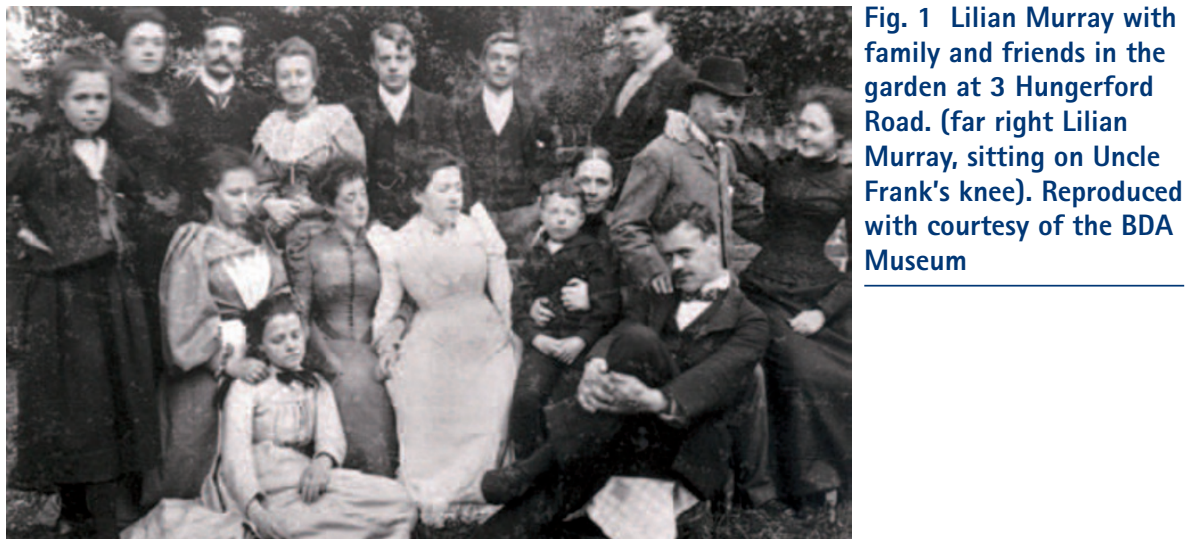

by the Society of Arts (Royal Society of Arts) in 1866. The Society went on to put up 35 plaques in London. The first two blue roundels were erected in 1867 to commemorate the birthplace of Lord Byron and the residence of Napoleon III. ${ }^{1}$

In 1901 the administration of the scheme passed to London County Council (LCC). The LCC was responsible for creating the familiar blue plaque design that was first used in the 1940s and in establishing formal selection criteria in 1954. Upon the disbanding of the LCC in 1965, the administration of the scheme passed to Greater London Council (GLC) and after the abolition of the GLC in 1986 to English Heritage. As custodian of the scheme, English Heritage has erected 360 plaques in the capital and has also taken on an advisory role, offering guidance on commemorative plaques to numerous groups, societies and organisations across the country. Severe cuts to its government funding in recent years, however, have led English Heritage to suspend nominations to the blue plaques scheme and to reduce its advisory role while it secures alternative ways of funding the scheme.

\section{THE CASE FOR LILIAN LINDSAY}

Lilian Murray was born at 29 Hungerford Road, Lower Holloway, in north London on 24 July 1871. Figure 1 depicts Lilian Murray with family and friends in the garden at 3 Hungerford Road, sitting on her uncle's knee. She attended Camden School for Girls, founded by Frances Mary Buss, and then won a two-year scholarship to North London Collegiate School in Camden where Miss Buss was headmistress. She wanted Lilian to become a teacher of deaf and dumb people but Lilian declined, adamant that she wanted to become a dentist. Buss was enraged and ensured her scholarship was not extended and so Lilian left the school. 
In 1860 the Royal College of Surgeons of England awarded the first qualification in dental surgery - the Licence in Dental Surgery (LDS). In 1881 the census recorded 214 women working as 'dentists', however, none were qualified.

Lilian was determined to become a qualified dentist and so was apprenticed to a dentist for three years, taking a preliminary examination before she registered as a dental student. In her autobiography, reprinted in the British Dental Journal (BDJ) in 1991, she states 'this was hard work but I had started on the road to dentistry and must not turn back. After one or two defeats I managed to pass, and to visit the Registrar of the General Medical Council who told me the next step must be to enter a dental school and suggested the National Dental Hospital (NDH) in Great Portland Street: ${ }^{3}$ In 1892 she applied to the National Dental Hospital where the Dean, Henri Weiss, would not allow her to enter the building, suggesting she might distract the men. Her interview was conducted in the street as he leaned out of the window. Lilian was refused admission to the NDH but Weiss suggested she apply to Edinburgh Dental Hospital and School. Here she was accepted by the Dean, William Bowman Macleod, but some of his colleagues were unhappy about accepting women. The treasurer, Sir Henry Littlejohn, tried to dissuade her even after accepting her fees, saying 'I am afraid, Madam, you are taking the bread out of some poor fellow's mouth.' Lilian was a talented student, gaining the Wilson Medal for dental surgery and pathology, and the medal for materia medica and therapeutics in 1894. In 1895 Lilian Murray became the first qualified British woman dentist, gaining the LDS with honours from the Royal College of Surgeons of Edinburgh.

The Royal College of Surgeons in England persisted in barring women from sitting its LDS examinations, twice voting against the proposal. Finally in 1908, it agreed to admit women to all its examinations and four years later Lily Fanny Pain, later Harwood (1889-1974) became the first woman to gain an LDS from the English College.

On her first day at dental school, Lilian met Robert Lindsay who had worked as Macleod's mechanic and was now a dental surgeon at the hospital. The couple formed an attachment but Lilian on qualification had financial as well as family commitments so she returned to London to practise at 69 Horney Rise, in Upper Holloway. She set up her first practice with a loan for rent and one hundred pounds for her equipment. 'I bought a dental engine for $£ 3$, a lathe and a vulcanizer. The dental chair cost $£ 14$ ! $^{3}$ After ten years she had repaid her debts and Lilian and Robert were married in the local church, St Luke's, Hillmarton Road, in 1905. They moved back to Edinburgh and set up a practice together at 2 Brandon Street.

A turning point came in 1920 when Robert was appointed secretary of the British Dental Association (BDA), in which capacity he was to play a vital part in the negotiations towards the Dentists Act of 1921. The couple moved to a flat above the BDA headquarters at 23 Russell Square (Fig. 2). The association started a small library and Lilian Lindsay became its honorary librarian. In 1921 the library consisted of 360 books and by 1951 there were $10,000 .{ }^{5}$ It was at this point that she started collecting dental objects and ephemera, which became the foundation of the BDA museum collection.

Lindsay was a prolific writer and charismatic speaker. Her first paper was published in 1912 while she was practising and a further 60 between 1925 and 1957. Her most important works include A short history of dentistry ${ }^{6}$ and her scholarly translation of the second edition of Pierre Fauchard's Le chirurgien dentist, 1746. ${ }^{7}$

On the death of her husband in 1930 Lilian dedicated even more time to her work and the BDA. She became subeditor for the $B D J$ in 1931, an office she was to hold for over 20 years. In 1933 she became the first woman branch president and in 1946 the first female president of the BDA.

Lindsay gained many honours and awards and was delighted to be appointed CBE in 1946. She received the degree of Doctor of Laws (honouris causa) from the University of Edinburgh in 1946 and a Higher Dental Diploma from the Royal College of Surgeons, Edinburgh in 1946. In 1959

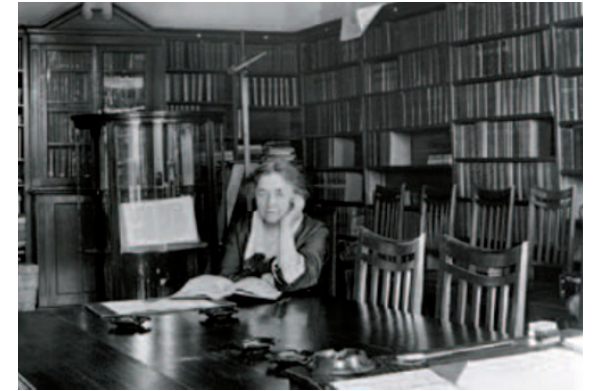

Fig. 2 Lilian Lindsay in the BDA library at 23 Russell Square c.1923. Reproduced with courtesy of the BDA Museum

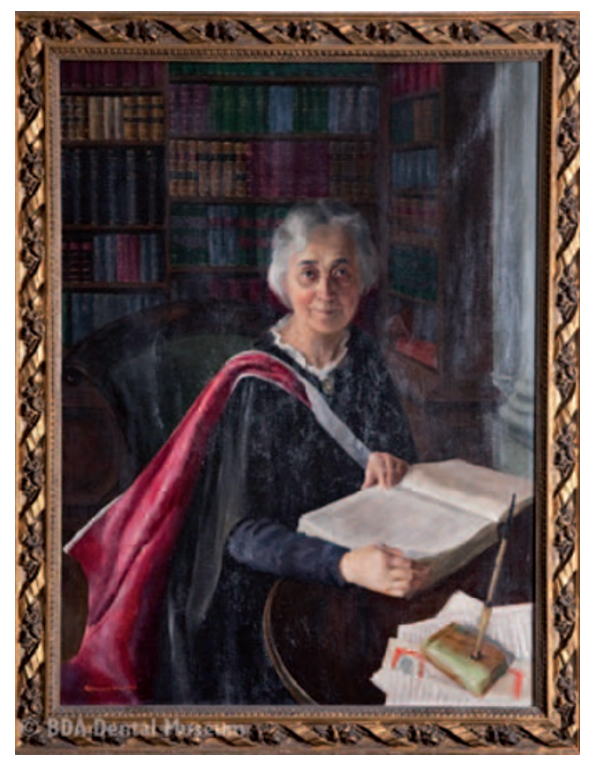

Fig. 3 Oil painting of Lilian Lindsay commissioned by the BDA using contributions collected from members and painted by Kathleen Williams in 1942. Photographed by Filip Gierlinski and reproduced with courtesy of the BDA Museum

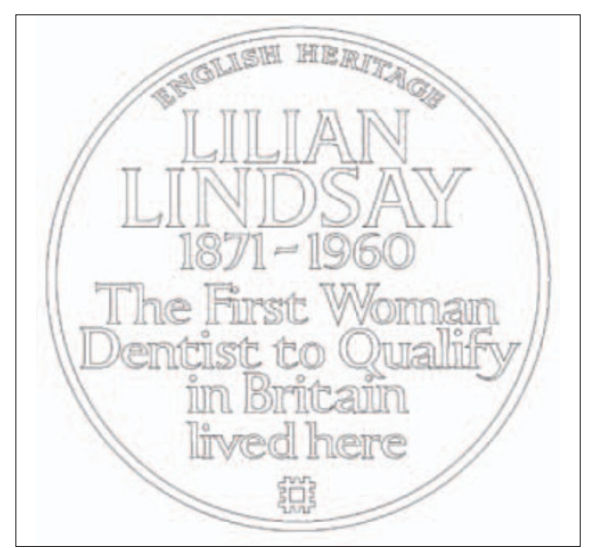

Fig. 4 Plaque design 2013. Reproduced with permission from English Heritage

the Edinburgh college awarded Lilian an honorary FDS. The RCS England also honoured her with the John Tomes Prize in 1945 and Colyer Gold Medal in 1959. At the Royal Society of Medicine she was the C E Wallis lecturer in 1933, president of the odontological section in 1945 


\begin{tabular}{|c|c|}
\hline Address of Lilian Lindsay & Verification/suitability for plaque \\
\hline $\begin{array}{l}\text { Born at } 29 \text { Hungerford Road } \\
\text { in } 1871\end{array}$ & House demolished \\
\hline $\begin{array}{l}\text { Lived at } 81 \text { Hungerford Road } \\
\text { (renumbered and now 3) }\end{array}$ & Home from 1872-1892 and site of plaque \\
\hline Edinburgh Dental School & Unknown address while a student \\
\hline 69 Hornsey Rise, London & $\begin{array}{l}\text { Practised and lived here between 1896-1905 } \\
\text { House demolished }\end{array}$ \\
\hline 2 Brandon Street, Edinburgh & Practised and lived here between 1906-1919 \\
\hline $\begin{array}{l}\text { Flat above the BDA at } \\
23 \text { Russell Square }\end{array}$ & $\begin{array}{l}\text { From January 1920-1937. The BDA moved from Russell Square in March } \\
1935 \text { but the Dentists Registers records this address for Lilian Lindsay } \\
\text { until 1937. } 23 \text { Russell Square is now part of SOAS, University of London }\end{array}$ \\
\hline $\begin{array}{l}\text { Flat in Hill Street near BDA } \\
\text { at } 13 \text { Hill Street }\end{array}$ & $\begin{array}{l}\text { Unconfirmed exact address. English Heritage can find no evidence she } \\
\text { lived at } 13 \text { Hill Street. Dentist Register states } 13 \text { Hill Street as address } \\
\text { from 1938-1959 }\end{array}$ \\
\hline $\begin{array}{l}\text { Flat in Lower Richmond Road, } \\
\text { Putney }\end{array}$ & $1939-1945$ \\
\hline $\begin{array}{l}\text { Flat at } 21 \text { Robert Adam Street, } \\
\text { W1 London }\end{array}$ & 1948. Address taken from voting paper in BDA library \\
\hline $\begin{array}{l}\text { Greendoors, } 54 \text { Church Street, } \\
\text { Orford, Suffolk }\end{array}$ & $\begin{array}{l}\text { Purchased by Robert and Lillian in } 1928 \text { for their retirement. Lilian lived } \\
\text { there from 1945-1960 until her death, along with her two sisters Evelyn } \\
\text { and Mary }\end{array}$ \\
\hline $\begin{array}{l}26 \text { Wolverton Avenue, } \\
\text { Kingston upon Thames }\end{array}$ & Place of death \\
\hline
\end{tabular}

and president of the history of medicine section in 1950. In 1938 Lindsay became president of the British Society for the study of orthodontics.

Lilian Lindsay died on 31 January 1960, aged 88. It is clear that she was a remarkable woman and that her life is worthy of commemoration (Figs 3 and 4).

\section{THE PROCESS FOR GETTING \\ A PLAQUE}

In 2004 an application was made to English Heritage by Professor Stanley Gelbier, later joined by the Lindsay Society for the History of Dentistry, to commemorate Lilian with a blue plaque. After careful consideration her name was shortlisted by the Blue Plaques Panel - which advises English Heritage on all new plaques suggestions - at its meeting in October 2004. Her name was added to the shortlist of suggestions awaiting detailed historical investigation by one of the historians in the Blue Plaques Team. Due to the popularity of the blue plaques scheme and the limited number of plaques that are erected each year, it takes several years for a suggestion reaches the top of the shortlist.

In 2010 Susan Skedd, Blue Plaques Historian at English Heritage, started the detailed research into Lilian Lindsay's case, which involved identifying and verifying all of her former addresses in London. Post office directories, census records, electoral registers, maps and street renumbering plans were some of the official sources consulted during the course of the research, as well as the BDA's own extensive archives. Lilian's exact whereabouts in the years following the BDA's move to 13 Hill Street proved particularly difficult to pinpoint. The authors continued to try to find evidence of Lindsay living at 13 Hill Street. Evidence was obtained from someone who worked in the $B D J$ office at the time that Lindsay actually lived further along the street. However, no official records could be found by English Heritage to support this claim.

One of the key tasks was to determine which addresses had survived and would be suitable for commemoration. It turned out that 69 Hornsey Rise, where Lindsay first practised, had been demolished, as had her birthplace address at 29 Hungerford Road. But her childhood address at 3 (formerly 81) Hungerford Road, Lower Holloway, was still standing. It was a promising contender for a plaque as it had been her family home for many years and it was while living there that she decided to train as a dentist. Table 1 shows Lilian Lindsay's various addresses and the reasons for their consideration.

As a result it was agreed that the most suitable place for a plaque in her honour would be at the renumbered 3 Hungerford Road, Islington, which had been her home from 1872 until 1892 when she left to study in Edinburgh. In June 2010 the Blue Plaques Panel approved the proposed site of the plaque and English Heritage began the negotiations to gain consent for the plaque from the owners of the property.

\section{PLAQUE DESIGN AND MANUFACTURE}

Once all the necessary consents were in place, the plaque was designed and manufactured; a process that takes at least two months. The design of blue plaques has gradually evolved since the outset of the scheme in the 1860s. The first plaques were made of encaustic ware plaques and intended to be blue, but blue proved to be difficult and expensive to manufacture, and so the plaques were more often than not brown in colour. The design included the name of the Society of Arts worked into the pattern around the edge. In 1901 the London County Council continued with the roundel, but introduced a laurel wreath border and ribbon embellishments to the standard plaque design and experimented with different colours and materials.

In 1921 the London County Council produced a detailed report on the design and material of the plaques with the intention of improving their appearance, longevity, suitability and cost effectiveness. Blue was chosen as the principal colour as it was deemed to stand out the best against London's buildings. In 1923 Royal Doulton was commissioned to produce the first glazed ware plaques. In 1938, the modern plaque design was created by a student at the Central School of Arts and Crafts. This design omitted the wreath and ribbon motif and simplified the layout. Carters Tile Company in Poole took over the manufacture of plaques when Doulton moved out of London in 1956. ${ }^{1}$ Since 1981 manufacture has been carried out by independent craftspeople. 
Manufacture is undertaken by the mixing and pouring of a thick clay slip into a casting mould. When sufficiently dry the cast is removed and the outline of the inscription and border are piped onto the face of the plaque. The plaque is then fired at $1,230{ }^{\circ} \mathrm{C}$ and glaze applied: white for the lettering and border, which are in low relief and blue for the background. The plaque is then fired a second and final time at a slightly lower temperature. The slightly domed design ensures that the plaque is self-cleaning and requires virtually no maintenance. The back is partially hollowed out to reduce the weight and to facilitate fixing to buildings. After firing, a plaque measures nineteen inches in diameter and is about two inches thick. ${ }^{1}$

Lilian Lindsay will only be the third dentist to have been honoured by the blue plaques scheme in London and will take her place alongside James Robinson and Sir Edwin Saunders. Curiously, there is no plaque to Sir John Tomes (1815-1895) who is considered to be the father of the BDA. He was considered for a plaque by the GLC in 1979, but there was no suitable surviving building to commemorate. Tomes was born in Weston in Avon in Gloucestershire and was apprenticed to an apothecary in Evesham before studying at Kings College and Middlesex Hospital Medical School. From 1840 to 1850 he lived and practised at 41 Mortimer Street (now in Cavendish Place), Marylebone, and between 1850 and 1873 he lived and worked at 37 Cavendish Square. In both instances the original buildings no longer exist. On his retirement in 1876 he moved to Upwood Gorse in Caterham, Surrey, which is outside the geographical remit of English Heritage's blue plaque scheme.

\section{JAMES ROBINSON (1813-1862)}

In 1991 a blue plaque to James

Robinson, the pioneer of anaesthesia and dentistry, was erected at 14 (formerly 7) Gower Street, Bloomsbury, which was his practice address from 1842 until his death (Fig. 5). The son of a naval captain, Robinson was born in Hampshire in 1813 (Fig. 6). At the age of 14 he was articled to a surgeon in London and after his apprenticeship he entered Guys Hospital and the London University where he studied the structure and diseases of the teeth. In 1830 he started as a chemist in Store Street, Bloomsbury, but soon decided to return to dentistry. In 1834 he was appointed surgeon dentist to the Metropolitan Hospital (now the Royal Free) and established a large and prestigious practice at Gower Street.

Robinson embarked on many different ventures throughout his life with great energy. He founded the first dental journal in Britain, the British Quarterly Journal of Dental Surgery which appeared in 1843 and Forceps. Although both were short-lived they established the periodical as the forum for the dental profession to share its ideas.

Robinson was deeply committed to improving the education and status of the dental profession. He believed that dentistry as a profession should be selfgoverning with its own incorporated body awarding diplomas. He was heavily involved with dental politics at the time and was the first president of the College of Dentists in 1856. He was integral to the foundation of the National Dental Hospital.

During Robinson's day, many

individuals administered anaesthetic agents in the decade 1835-1845. On 16 October 1846, at Massachusetts General Hospital in Boston, the first public demonstration of ether anaesthesia took place. The anaesthetist was William Morton and the surgeon was John Warren; the operation was the removal of a lump under the jaw of Gilbert Abbott. Present in the room was another surgeon, Jacob Bigelow, who wrote a letter to a friend in London that described the process. This letter was carried on the mail boat SS Arcadia, which docked in Liverpool in mid-December 1846.

On 19 December 1846 in both Dumfries and London, ether anaesthetics were given. Few details are available about the Dumfries anaesthetic, but it is believed that the patient had been run over by a cart and required an amputation of his leg; it is also believed that he died. At the home of an American botanist, Francis Boott, James Robinson removed a tooth of a Miss Lonsdale under ether anaesthesia. Two days later at University College Hospital, Robert Liston amputated the leg

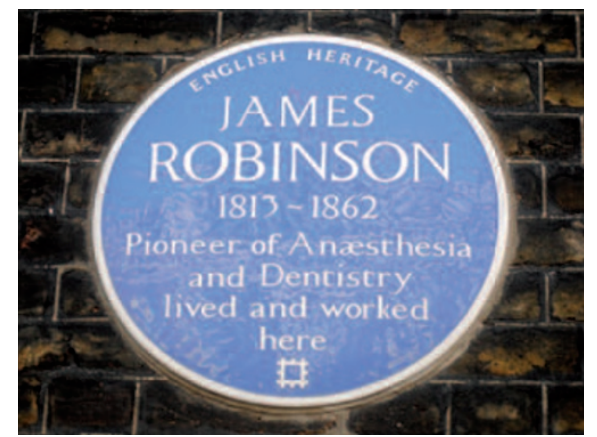

Fig. 5 Plaque to commemorate James Robinson

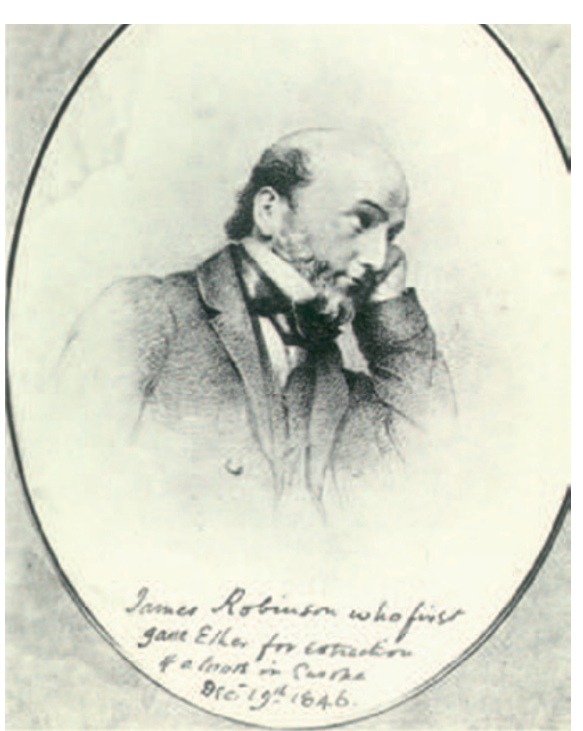

Fig. 6 Portrait of James Robinson. Reproduced with courtesy of the BDA Museum

of a chauffeur Frederick Churchill while a medical student called William Squires gave an ether anaesthetic. ${ }^{8}$

Robinson wrote to the Medical Times on 28 December 1847 reporting details of his experiments so far in which he predicted the far reaching effects of anaesthesia. ${ }^{9}$ He continued to trial his techniques and to demonstrate them to a wide variety of audiences. He devised his own apparatus for administering ether and these received the widest publicity. His observations formed the basis for the first book on anaesthesia which was published in March 1847 entitled A treatise on the inhalation of the vapour of ether. ${ }^{10}$ In this he presented 25 of his own case studies and details of his apparatus and method. Within a few weeks inhalation anaesthesia became generally accepted in Britain mainly due to the efforts of James Robinson.

James Robinson withdrew from the forefront of anaesthesia by April 1847 after only four months. Why he did so is not clear but he moved on to other areas 


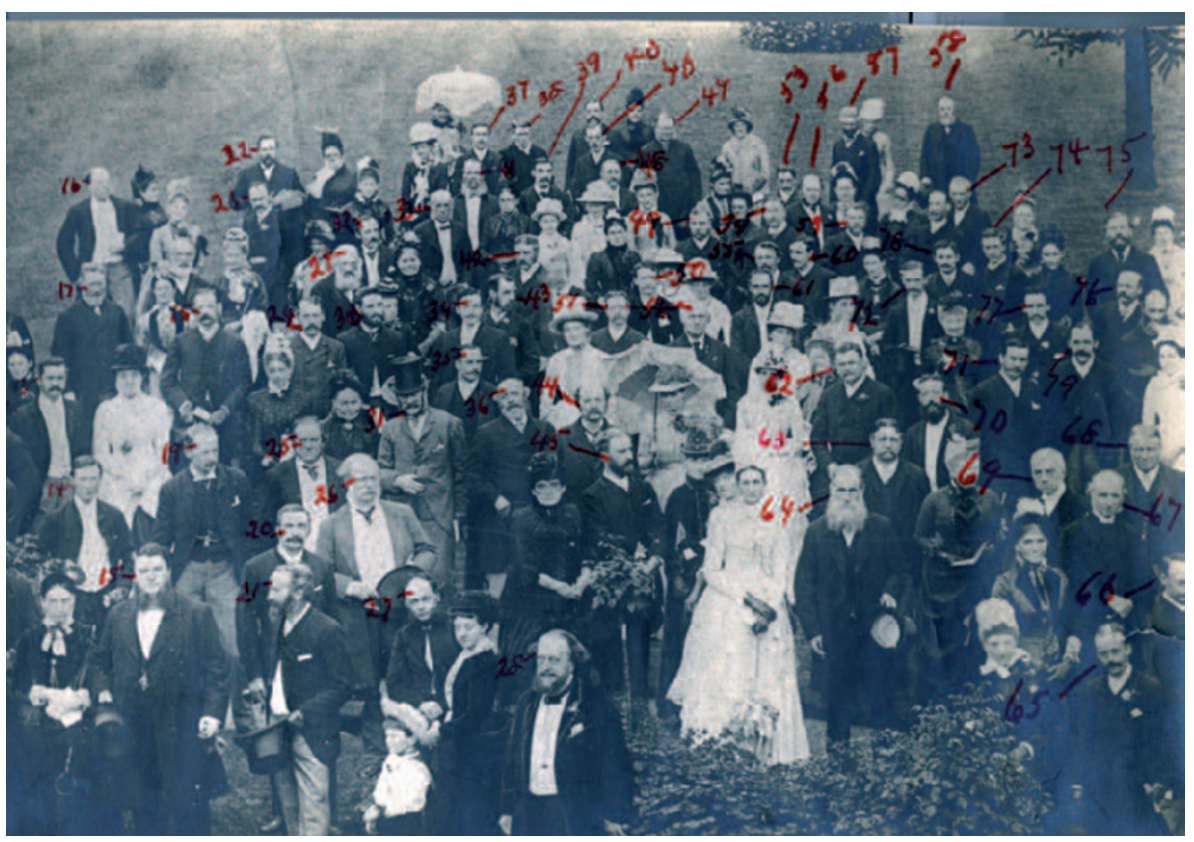

Fig. 7 Garden party at Fairlawns in 1886. Reproduced with courtesy of the BDA Museum

of interest. Tragically, James Robinson died on 4 March 1862 as a result of a gardening accident.

\section{EDWIN SAUNDERS (1814-1901)}

Edwin Saunders was the son of a book publisher and from an early age he showed great aptitude for all things mechanical. He toyed with the idea of engineering but took an opportunity to be apprenticed to Mr Lemaile in dental mechanics. He started by giving lectures on dental mechanics and was soon giving lectures at St Thomas Hospital. In 1836 he set about to study the eruption of children's teeth, particularly those of children who illegally worked in factories. Children aged under nine were not allowed to work in factories as a result of the 1802 Factory Act. However, parents were often financially desperate for their children to work and frequently lied about their children's ages. Saunders published the results of his survey in The teeth, as a test of age with reference to factory children. ${ }^{11}$ This was presented to members of parliament.

In 1840 Saunders founded the London Institute for the Diseases of the Teeth in Windmill Street, Tottenham Court Road. Its purpose was to provide treatment to the poor and for students to gain some experience under the supervision of experience practitioners. The institution was the first of its kind in Europe.

While working on cleft palate research he met Alexander Nasmyth and in 1846 took over his practice at 13A George Street, Hanover Square. Shortly after this he was appointed surgeon dentist to Queen Victoria and her family. He served them for over 40 years and was awarded a knighthood in $1883 .{ }^{12}$

Saunders played an important part in the development of dentistry between the 1850s and 1870s. He campaigned with Sir John Tomes and other leading dentists for regulation within the profession and the establishment of the BDA. In 1886 he was elected president of the association and hosted a garden party at his home, Fairlawns (the site of the plaque) (Figs 7 and 8). He was instrumental in the foundation of the Odontological Society, which was formed at his Mayfair home in 1856. He was the society's treasurer and then president. A portrait of Saunders is illustrated in Figure 9. He was a trustee of the Dental Hospital of London and as a generous benefactor enabled its move from Soho Square to Leicester Square. Figure 10 displays Saunder's instrument set.

The blue plaque to Saunders was erected in 1997 by English Heritage on the gate pier of his former home at Fairlawns, 89 Wimbledon Park Side. It is a substantial detached house built by Saunders in 1853 to designs by the architect Rawlinson Parkinson. It was his permanent home from 1894 until his death in 1901.

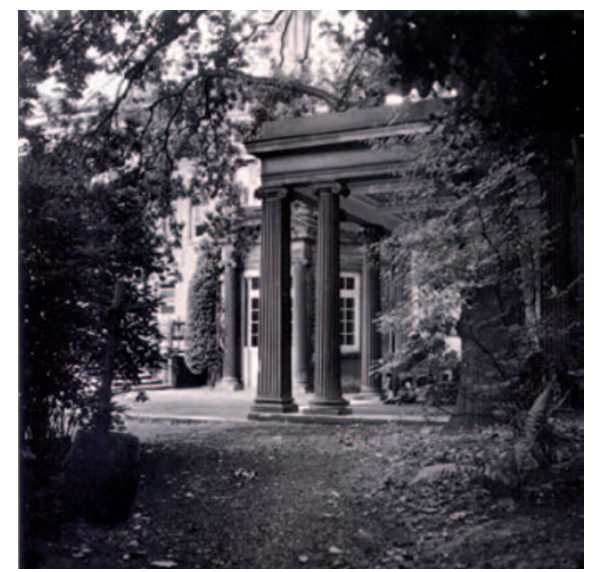

Fig. 8 View rear of Fairlawns, site of the plaque. Reproduced with courtesy of the BDA Museum

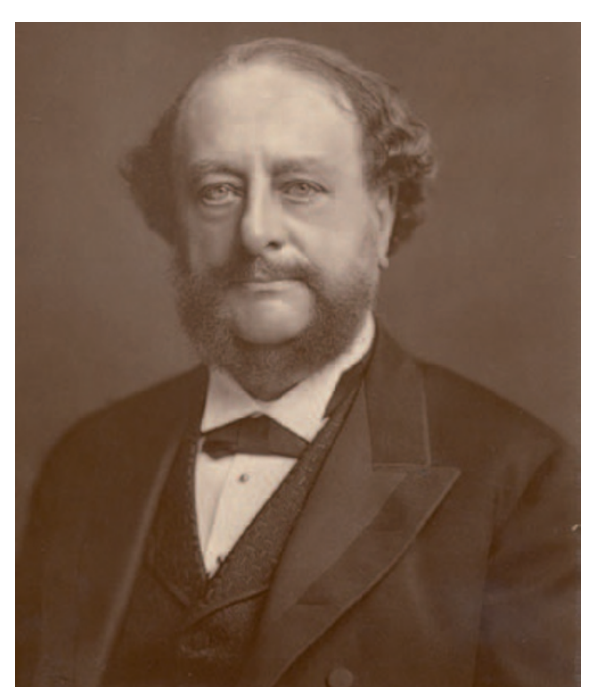

Fig. 9 Portrait of Edwin Saunders. Reproduced with courtesy of the BDA Museum

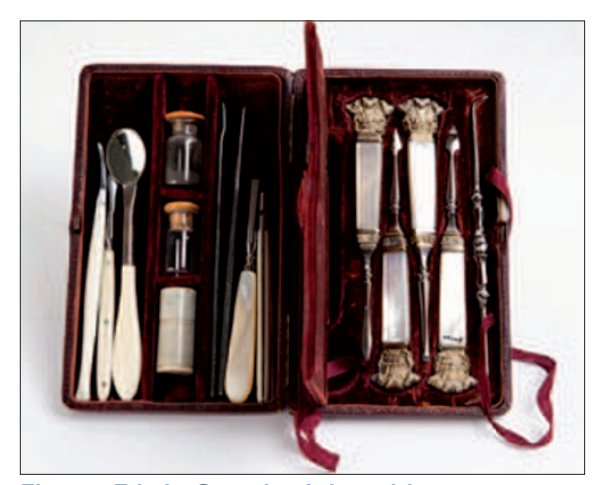

Fig.10 Edwin Saunders' dental instrument set. Photographed by Filip Gierlinski and reproduced with courtesy of the BDA Museum

OTHER PLAQUES TO DENTISTS: FRANK HARRISON (1859-1912)

Research has revealed the whereabouts of two plaques commemorating dentists elsewhere in the country. The first is installed on a semi-detached stucco house dating from about 1825 at 297 (previously 289) Glossop Street in Sheffield. The plaque commemorates 
Frank Harrison who practised at this address (Fig. 11). It was erected by the British Society of Dental and Maxillofacial Radiology and unveiled by Keith Horner, Professor of Oral and Maxillofacial Imaging at Manchester University and President of the Society in July $2005 .{ }^{13}$

Frank Harrison was born in Sheffield in August 1859, the son of a dentist Joseph Harrison. He received his medical and dental training in Sheffield, Edinburgh and Charing Cross hospital in London. He gained his LDS in 1881 from Edinburgh and returned to Sheffield to set up in practice with his father. He was instrumental in setting up the Dental Department of Sheffield Royal Hospital and the School of Dental Surgery in 1898. His interests were wide and varied and he lectured and published many books and papers. He published a book with Richard Denison Pedley entitled Our teeth in 1908 (Fig. 12).${ }^{14}$ He was a member of the Representative Body of the BDA and the President of the Midland Counties branch and a frequent demonstrator of his innovations at BDA conference.

In 1896 the world was caught up with the excitement of what was then termed the new photography. Edmund Kells in New Orleans, Keonig and Walkhoff in Germany and Frank Harrison in the UK were all producing crude but recognisable 'skiagrams'. It is difficult to know who produced the first radiograph but Frank Harrison was certainly the first in the world to discuss and reproduce them in his papers ' $X$-rays in the practice of dental surgery' 15 and 'The new photography and its application to dental practice' published in the British Dental Journal in 1896. ${ }^{16}$. It was based on his paper presented to the Midland Counties branch of the BDA on 26 June in 1896. In it he explains the potential for the use of X-rays, particularly in the provision of artificial crowns, the treatment of roots and in cases of difficult eruption of teeth. He illustrates his paper with glass lantern slides. ${ }^{17}$

It is interesting to note that Harrison's $B D J$ obituary and appreciation makes no reference to his contribution to dental radiology. He died abruptly at the age of 52 years following a short illness.

\section{GEORGE CUNNINGHAM}

(1852-1919)

The second plaque known to be in existence is the brown plaque at 2 King's Parade in Cambridge, which commemorates George Cunningham, 'the father of UK preventive dentistry', who practised at this address from 1883 to 1919.

George Cunningham (Fig. 13) was born in 1852 in Edinburgh. He studied medicine at university and lived in Paris. Cunningham was one of three Englishman to graduate from the New Harvard School of medicine in 1876. He graduated as a doctor of dental medicine (DMD) with honours, which enabled him to gain his LDS without further examination. After Harvard he travelled around the USA visiting leading practitioners and became imbued with the concept of conservative dentistry. He returned to England and set up his own practice at 2 King's Parade in Cambridge in 1883.

Cunningham continued to be an active figure in international dentistry and attended many congresses throughout his life. Together with Charles Godon, Cunnningham helped to set up an international organisation of leading dentists - the Federation Dentaire International (FDI). ${ }^{18}$

At the annual general meeting of the association in 1886 he read a masterly paper 'Dentistry and its relation to the state. ${ }^{19}$ This was a devastating expose of the appallingly high number of incidents of dental disease in the armed services and the inadequacy of treatment. His attempts to galvanise the BDA and in turn government into providing services for the armed forces finally resulted in the appointment of four dental surgeons to treat soldiers serving in South Africa in $1901 .^{18}$

Cunningham was also active in workplace and industrial dentistry. Cunningham co-authored the 1899 report to the Home Secretary on the use of phosphorus in the manufacture of Lucifer matches. ${ }^{20}$ His detailed contribution involved visits to 25 main match factories and the examination of large numbers of workers' mouths. He concluded that fumes of yellow phosphorus caused no harm but in an unhealthy mouth could lead to chronic necrosis of the bones of the jaws, which

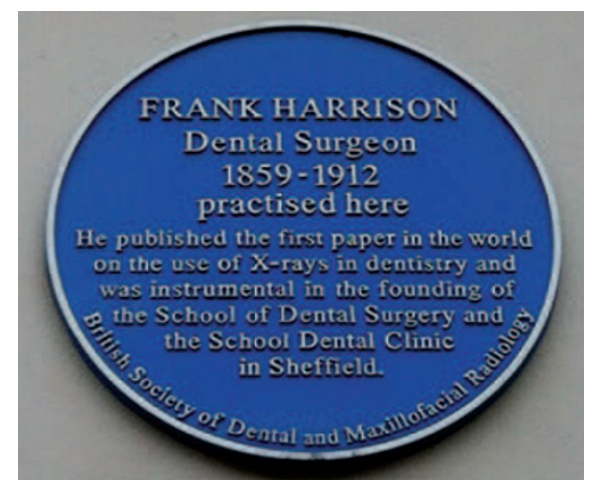

Fig. 11 Plaque to Frank Harrison. Photographed by Sam Smith

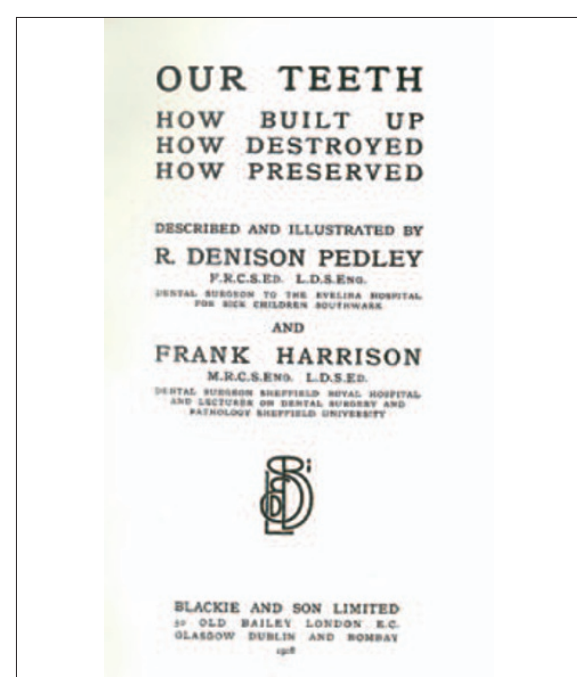

Fig. 12 Our teeth, 1908 written by Richard Dennison Pedley and Frank Harrison. Reproduced with courtesy of the BDA Library

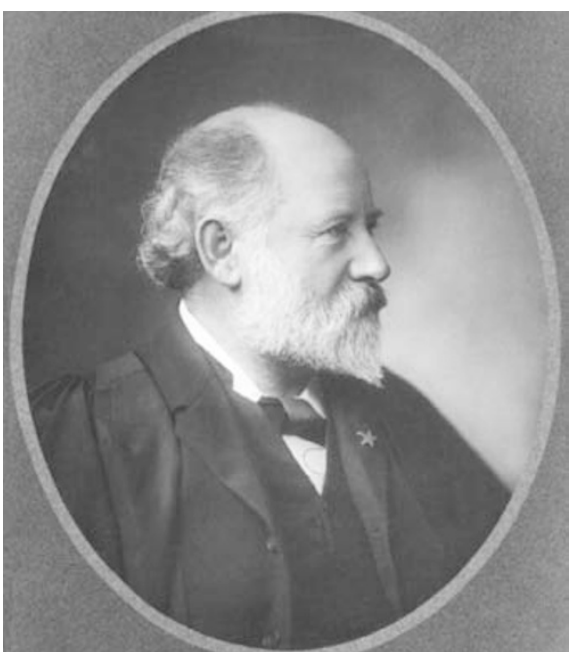

Fig. 13 George Cunningham. Reproduced with courtesy of the BDA Museum

was known at the time as phossy jaw. His examinations revealed the appalling dental condition of the working class and he recommended compulsory dental examinations, hygienic working conditions and the provision of mouthwashes and other facilities. The 


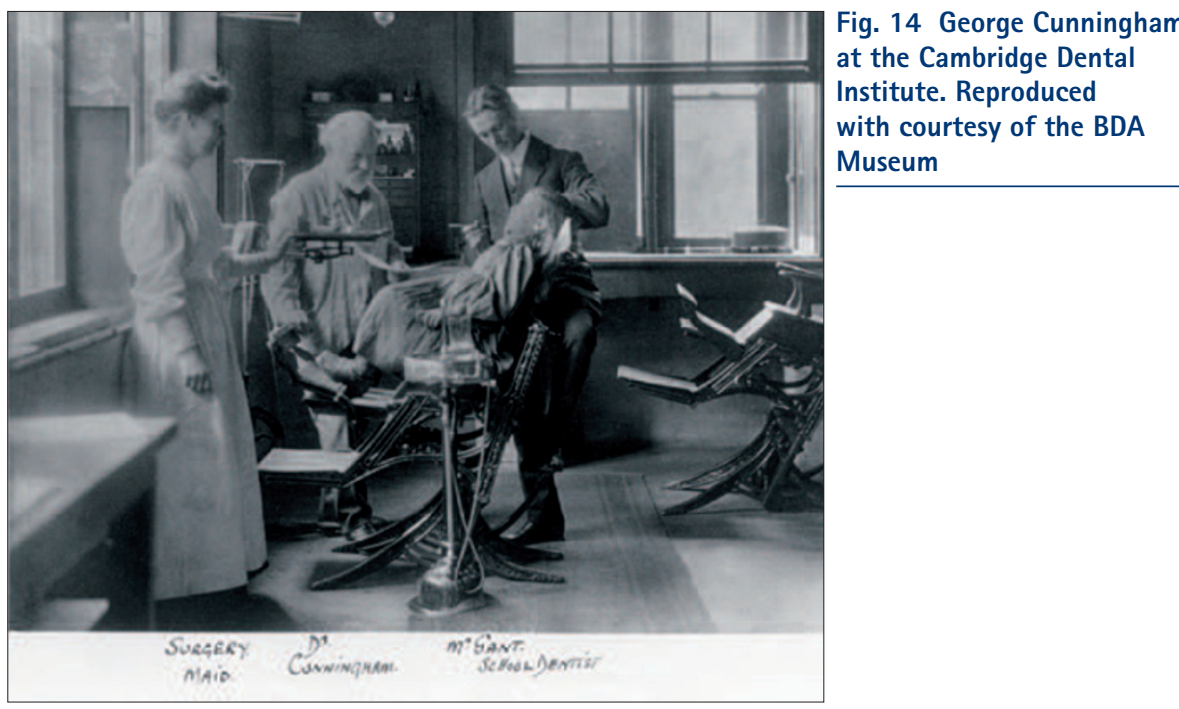

report finally led to the prohibition of the use of yellow phosphorus in the manufacture of matches in 1906. ${ }^{18}$

But it is Cunningham's dedication to preventive dentistry and promotion of oral hygiene that he is most remembered for. As a prominent member of the representative board's school children's committee 'to conduct the collective investigation as to the condition of the teeth of school children', he was aware of the desperate need for preventive dental treatment and education of parents and children. The committee presented seven detailed reports between 1891 and 1897 but no action followed. Cunningham was disappointed but not undeterred and he independently set up the Cambridge Dental Institute in 1907 (Fig. 14). The clinic was the first of its kind and it aimed to provide conservative treatment and oral health education. All extractions took place at the local hospital. The clinic was designed with a playroom and garden. ${ }^{21}$ In 1908 the clinic formed part of the school dental service marking a turning point in dental health services.

He was an early member of the BDA from its inception in 1880 and continued to be an active member, being instrumental in the formation of the Eastern Counties Branch. The plaque was erected by the Eastern Counties Branch of the BDA in the 1980s. ${ }^{22}$

\section{OTHER MEDICAL FIGURES WITH CONNECTIONS TO DENTISTRY}

Among the numerous plaques commemorating leading medical practitioners, three stand out which have a connection with dentistry, notably those to Sir Harold Gillies, John Hunter and John Clover. Sir Harold Gillies (1882-1960) was a pioneer plastic surgeon. During the First World War as a result of disfiguring facial injuries he began to reconstruct faces. During the Second World War he was responsible for plastic surgery units throughout the country. An English Heritage blue plaque was erected on his former home at 71 Frognal, Hampstead, in 1997.

The plaque to commemorate John Clover (1825-1882) was erected at 3 Cavendish Place, Marylebone, by Westminster City Council in collaboration with the History of Anaesthesia Society. Clover was a pioneer in anaesthetics. He carried on James Robinson's work and devised new means of administering ether and chloroform (Fig. 15).

The surgeon and anatomist John Hunter (1728-1793) made a great contribution to our understanding of medicine and dentistry. His work The natural history of human teeth: explaining the structure, use, formation, growth and diseases ${ }^{23}$ in 1773 accurately described the structure of the teeth based upon his detailed observation of the anatomy of the jaws and mouth (Fig. 16). The plaque was erected on his home at 31 Golden Square.

It is not always an individual that is commemorated on a plaque as the following example demonstrates. There is a commemorative plaque at Birmingham Dental Hospital. The metal plaque was

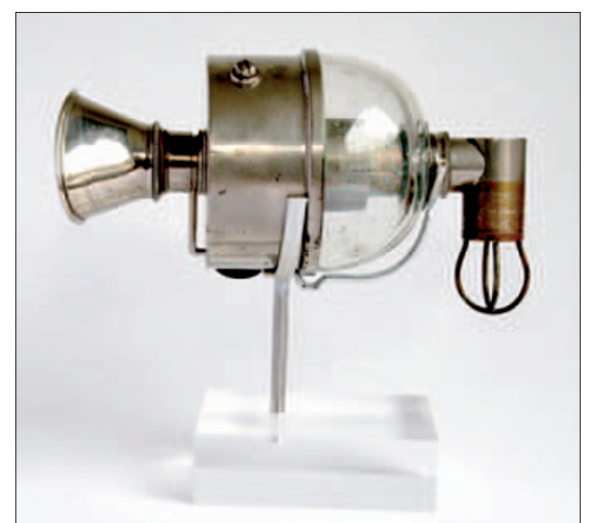

Fig. 15 John Clover's portable regulating ether inhaler, c. 1880 . Photographed by Filip Gierlinski

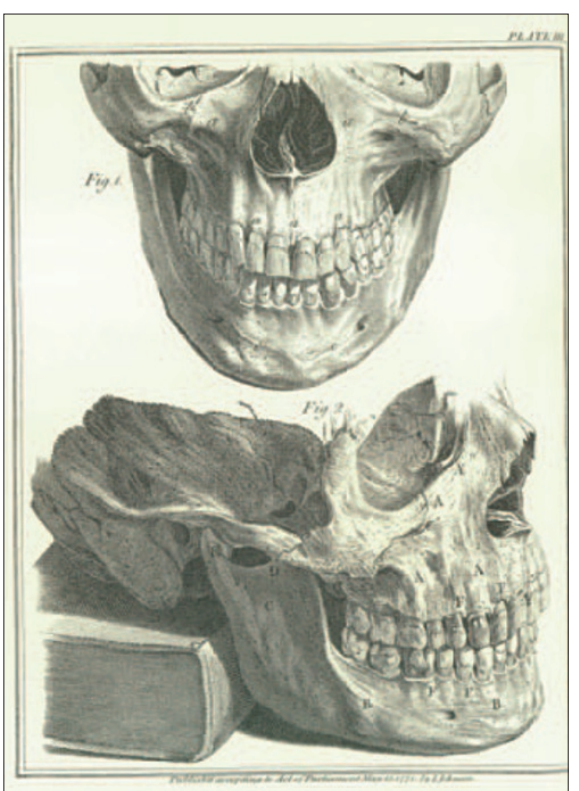

Fig. 16 Illustration from John Hunter's work of 1773 showing the front view of the upper and lower jaws of an adult with a full set of teeth. Reproduced with courtesy of the BDA Library

erected by Birmingham Civic Society in 1958. It was re-sited in 1965 when the present building was opened. The tablet commemorates the centenary of the Hospital, which was founded in January 1858 as the result of the inspiration and charitable endeavours of Samuel Adam Parker, Dental Surgeon and his associates. It was unveiled by the Right Worshipful the Lord Mayor of Birmingham, Alderman Donald Johnstone on 7 June 1958. The current location of the plaque is unknown.

This is by no means an exhaustive list of the commemorative plaques of interest to the dental community and the authors would be interested to hear of any others spotted by readers of this paper. 


\section{ANOTHER MEMORIAL FOR LILIAN LINDSAY}

The Lindsay Society for the history of dentistry was formed in 1962 to promote interest, study and research into the history of dentistry. It brings together members of the dental profession, historians and other interested people to research and discuss the history of dentists and dentistry.

Each year the society hosts the Lilian Lindsay Memorial Lecture at the BDA conference (www.bda.org/lindsaysociety). It also organises an annual conference with expert speakers from within and outside the profession. Drawing on the success of 2012's anniversary conference this year's meeting will take place in Maidstone between 4-6 0ctober.

Further information about the Society and conference are available from Brian Williams, the honorary secretary, at brianwilliams14@btinternet.com.
The authors wishes to thank Jane Biro and Dr Susan Skedd from English Heritage, Shirley Zangwill from the BDA Eastern Counties Branch, Rita McLean from Birmingham Civic Society and Professor Deborah White at Birmingham Dental Hospital and School. Also to Peter Hirschmann and Dr Vivian Rushton for sharing their research regarding Frank Harrison. Also to Melanie Parker for access to her research into the addresses of Sir John Tomes. Special thanks to Margaret Murray and members of the Murray family for their kind help and access to the family archives.

1. Cole E. Lived in London: blue plaques and the stories behind them. London: Yale University Press, 2008.

2. Rennison N. The London blue plaque guide. London: The History Press, 2009.

3. Cohen $\mathrm{R}$, Cohen $\mathrm{M}$. The autobiography of Lilian Lindsay. Br Dent J 1991; 171: 325-328.

4. Cohen R. Lilian Lindsay 1871-1960. Brighton; The Southern Publishing company 1973.

5. Hillam C. The remarkable career of an accidental heroine: Lilian Lindsay (1871-1960). Dent Hist 1997; 32: 23-39

6. Lindsay L. A short history of dentistry. London: J Bale Sons and Danielsson Ltd, 1933.

7. Fauchard P. The surgeon dentist or treatise on the teeth. Translated by Lilian Lindsay. London Butterworth and Co Ltd, 1946.

8. Hillam C. James Robinson (1813-1862) professiona irritant and Britain's first anaesthetist. Edinburgh: Second Lilian Lindsay Memorial Lecture, 1996

9. Robinson J. Medical Times 1847; 15: 273-274.

10. Robinson J. A treatise on the inhalation of the vapour of ether, for the prevention of pain in surgical operations. London: Webster and Co, 1847.
11. Saunders E. The teeth a test of age, considered with reference to the factory children addressed to the members of both houses of Parliament. London: Renshaw, 1837.

12. The obituary of Sir Edwin Saunders. Br Dent J 1901 22: 200-203.

13. Hirschmann P. Frank Harrison (1859-1912). Dent Hist 2006; 43: 62-66.

14. Denison Pedley R, Harrison F. Our teeth: how built up, how destroyed, how preserved. London: Blackie and Son, 1908.

15. Harrison F. The 'x-rays' in the practice of dental surgery. Br Dent J 1896; 17: 624-628.

16. Harrison F. The new photography and its application to dental practice. Br Dent J 1896: 17: 343-344.

17. Figures K, Smith C. A profile of Frank Harrison: a pioneering Sheffield dentist from 100 years ago. Br Dent J 2012; 213: 405-408.

18. Davis C. George Cunningham: the man and his message. Br Dent J 1969; 127: 527-537.

19. Cunningham $G$. Dentistry and its relation to the state. Br Dent J 1886; 7: 49

20. Thorpe TE, Oliver T, Cunningham G. Reports on the use of phosphorus in the manufacture of lucifer matches. London: Eyre and Spottiwoode, 1899.

21. Obituary of George Cunningham. Br Dent J 1919; 40: 217-223.

22. Zangwill S. Onward the toothbrush brigade: George Cunningham, pioneer of preventive dentistry. History of Dentistry Newsletter 2001; 9: 21. Online article available at http://historyofdentistry.co.uk/index htm_files/20010ct8.pdf (accessed August 2013).

23. Hunter J. The natural history of human teeth: explaining the structure, use, formation, growth and diseases. London: J Johnson, 1771. 